\title{
Pendidikan Anak Usia Dini (PAUD) \\ Dalam Pendekatan Psikologi Anak
}

\author{
Nabil \\ STIT Al Marhalah Al Ulya Bekasi \\ Email: anisbata124@gmail.com
}

\begin{abstract}
In the point of psychology, the phenomenon of early childhood education is a necessity. Because the development of the human brain at an early age (0 to 6 years) accelerates to $80 \%$ of the overall adult brain. Often the early age is often referred to as the golden age (golden age) in the development of human history. Maria Montessori said that this period is a sensitive period in which children easily receive stimuli from their environment. It is during this sensitive period that physical and psychological functions are matured so that the child is ready to respond and realize all the developmental tasks that are expected to appear in his daily behavior patterns.

The conceptual foundation that underlies the importance of PAUD is the discovery of experts about child development, especially in the field of neuroscience and psychology. Growth and development of children can not be released by the development of brain structures. According to Wittrock there are three areas of brain development that experience rapid increase at an early age, namely the growth of dendritic fibers, the complexity of synaptic relationships, and division of nerve cells. The three brain regions are very important to develop from an early age, because at this age the three brain regions experience maximum development, which is $80 \%$ of the overall adult brain development. After children aged 6 years and older until adulthood, their development does not exceed $20 \%$.
\end{abstract}


Nabil

\section{Pendahuluan}

Dalam sudut ilmu psikologi, fenomena pendidikan Anak Usia dini merupakan suatu keniscayaan. Pasalnya, perkembangan otak manusia pada usia dini (0 sampai 6 tahun) mengalami percepatan hingga $80 \%$ dari keseluruhan otak orang dewasa. Seringkali masa usia dini sering disebut dengan the golden age (usia emas) dalam perkembangan sejarah manusia. Maria Montessori mengatakan bahwa masa ini merupakan periode sensitif dimana anak secara mudah menerima stimulus-stimulus dari lingkungannya. ${ }^{1}$ Pada masa peka inilah terjadi pematangan fungsi-fungsi fisik dan psikis sehingga anak siap merespon dan mewujudkan semua tugas-tugas perkembangan yang diharapkan muncul pada pola perilakunya sehari-hari.

Berdasarkan teori perkembangan anak, diyakini bahwa setiap anak lahir dengan lebih dari satu bakat. Untuk itulah anak perlu diberikan pendidikan yang sesuai dengan perkembangannya dengan cara memperkaya lingkungan bermainnya. Orang dewasa perlu memberi peluang pada anak untuk menyatakan diri, berekspresi, berkreasi, dan menggali sumber-sumber terunggul pada anak. Untuk itu, paradigma baru bagi ana usia dini atau anak prasekolah adalah harus berorientasi pada anak (student centered) dan prlahan-lahan menyeimbangkan dominasi pendekatan lama yang berpusat pada guru (teacher centered).

Pada hakitkatnya anak adalah makhluk individu yang membangun sendiri pengetahuannya. Anak lahir membawa sejumlah potensi yang siap untuk ditumbuh kembangkan asalkan lingkungan menyiapkan situasi dan kondisi yang dapat merangsang kemunculan dari potensi yang tersembunyi tersebut.

\footnotetext{
1. Maria Montessori, Metode Montessori (Panduan Guru Dan Orang Tua Didik Paud), (Yogyakarta: Pustaka Pelajar, 2000), hlm. 20

- 74 -
}

Al Marhalah : Jurnal Pendidikan Islam. Volume. 1, No.2 November 2017 
Berdasarkan tinjauan aspek pedagogis, masa usia dini merupakan masa pondasi awal bagi pertumbuhan dan perkembangan selanjutnya. Diyakini bahwa masa kanak-kanak yang bahagia merupakan dasar bagi keberhasilan di masa mendatang dan sebaliknya. Jadi, agar tumbuh kembangnya tercapai secara optimal dibutuhkan situasi dan kondisi yang kondusif pada saat memberikan stimulus dan pendidikan yang sesuai dengan kebutuhan dan minat anak. Secara teoritis berdasarkan aspek perkembangannya, seorang anak dapat belajar dengan sebaik-baiknya apabila kebutuhan fisiknya terpenuhi dan mereka merasa aman dan nyaman secara psikologis.

Tetapi selama ini lembaga pendidikan usia dini yang tersedia adalah Taman Kanak-kanak (TK) maupun Raudhatul Athfal (RA). Pendidikan TK atau RA hanya menerima anak usia 4-6 tahun. Padahal, menurut hasil temuan-temuan bidang neuroscience dan psikologi, pendidikan seharusnya diberikan sejak dini.

Pada hakikatnya, pendidikan anak usia dini merupakan salah satu bentuk penyelenggaraan pendidikan yang menitikberatkan pada peletakan dasar ke arah pertumbuhan dan perkembangan fisik (koordinasi motorik halus dan kasar), kecerdasan (daya pikir, daya cipta, kecerdasan emosi, kecerdasan spiritual), sosio emosional (sikap dan perilaku serta agama) bahasa dan komunikasi, sesuai dengan keunikan dan tahap-tahap perkembangan yang dilalui oleh anak usia dini.

Dari uraian diatas dapat ditarik suatu analisis. Penulis berusaha melakukan penelitian Pendidikan Anak Usia Dini (PAUD) dalam pendekatan psikologi anak . 
Nabil

\section{Landasan Historis}

Pada Tahun 2005, UNESCO mengatakan bahwa Indonesia merupakan negara yang angka partisipasi Pendidikan Anak Usia Dini (PAUD) terendah di ASEAN, baru sebesar 20\%, ini masih lebih rendah dari Fhilipina (27\%), bahkan negara yang baru saja merdeka Vietnam (43\%), Thailand (86\% dan Malaysia (89\%). Dan kesemunya ini semakin tampak dengan Human Development Index (HDI) Indonesia yang juga lebih rendah diantara negara-negara tersebut. Ini membuktikan bahwa pembangunan PAUD berbanding lurus dengan mutu dari sebuah negara yang terdiskripsikan dalam HDI.

Sedangkan Depdiknas dalam buku Pembangunan Pendidikan Nasional tahun 2007 menggambarkan bahwa Pemerintah telah berhasil meningkatkan Angka Partisipasi Kasar (APK) PAUD yang awalnya pada tahun 2004 adalah 39,09\% maka pada tahun 2006 sudah mencapai 45,63\% dengan target capaian pada tahun 2007 sebesar 48,07\%, sudah barang tentu ini merupakan sebuah hal yang menggembirakan bagi pengembangan pendidikan anak usia dini. Kemudian disebutkan bahwa agenda-agenda yang akan dicapai pada tahun 2009 seperti pencapaian APK PAUD usia 2 - 6 tahun sebesar Akan tetapi perlu dikritisi untuk pencapaian 53,90\% atau sekitar 10,05 juta orang kualitas dari layanan yang diberikan, bukan kepada kuantitas. Ini menjadi amat penting karena begitu dasarnya PAUD itu bagi seorang manusia dalam kehidupannya yang akan datang.

Pemerintah pada tahun 2001 telah mendirikan Direktorat khusus bagi PAUD yaitu Direktorat Pendidikan Anak Dini Usia dibawah naungan Direktorat Jenderal Pendidikan Luar Sekolah (sekarang disebut Ditjen PNFI), Direktorat yang bertugas untuk melayani PAUD pada jalur pendidikan nonformal dan informal. Ini disebabkan karena sebelumnya untuk layanan 
yang diberikan kepada anak usia dini baru pada usia $4-6$ tahun melalui pendidikan formal yaitu TK, sedangkan melalui jalur pendidikan nonformal dan informal msih belum ada. Pendidikan formal pada tahun 2000 hanya mampu menyerap $12,65 \%$ dari total usia tersebut dengan Guru TK hanya sebanyak 95.000 orang untuk memberikan pelayanan 1,6 juta anak usia dini. Sedangkan untuk sisa $0-4$ tahun masih belum terlayani, oleh karena itu maka Pemerintah berinisiatif untuk mendirikan Direktorat PADU (saat ini disebut Dit.PAUD) yang bertugas untuk melayani anak usian dini yang berumur $0-4$ tahun.

Untuk bidang SDM dalam pengembangan PAUD ini dijabarkan dalam PP Nomor 19/2005 tentang Standar Nasional Pendidikan pasal 29 yang menjelaskan bahwa standar minimal bagi Pendidik PAUD adalah D-IV atau Sarjana dengan latar belakang pendidikan PAUD, psikologi atau pendidikan lainnya yang telah bersertifikasi profesi guru untuk PAUD. Yang kesemuanya merupakan bentuk perhatian Pemerintah betapa pentingnya PAUD bagi bangsa ini.

Pembentukkan unit eselon I untuk mengelola PAUD juga dirasakan amat penting dan harus secepatnya dapat dilakukan untuk mempermudah koordinasi dan kesinambungan program yang dilakukan karena saat ini tidak hanya Depdiknas yang mempunyai program bagi PAUD tetapi tersebar juga pada instansi lain. Departemen Kesehatan dengan program fasilitasi kesehatan gizi seorang anak, Departemen Sosial dengan program kesejahteraan anak, dan Departemen Agama memberikan program untuk dapat memfasilitasi PAUD pada lembaga-lembaga Agama, serta kesemuanya memerlukan sebuah koordinasi untuk dapat melakukan percepatan pengembangan PAUD. 
Nabil

\section{Landasan Konseptual}

Landasan konseptual yang mendasari pentingnya PAUD adalah penemuan para ahli tentang tumbuh-kembang anak, khususnya di bidang neuroscience dan psikologi. Pertumbuhan dan perkembangan anak tidak dapat dilepaskan dengan perkembangan struktur otaknya. Menurut Wittrock ada tiga wilayah perkembangan otak yang mengalami peningkatanb pesat pada usia dini, yaitu pertumbuhan serabut dendrit, kompleksitas hubungan sinapsis, dan pembagian sel saraf. Ketiga wilayah otak tersebut sangat penting untuk dikembangkan sejak usia dini, karena pada usia inilah ketiga wilayah otak mengalami perkembangan secara maksimal, yakni $80 \%$ dari perkembangan otak orang dewasa secara keseluruhan. Setelah anak usia 6 tahun keatas hingga masa dewasa, perkembangannya tidak lebih dari $20 \%$.

Teyler menyatakan bahwa saat lahir otak manusia berisi 100 miliar hingga 200 miliar sel saraf. Setiap sel saraf siap berkembang sampai taraf tertingi dari kapasitas manusia jika mendapatkan stimulasi yang sesuai dari lingkungan.Berdasarkan keterangannya, maka inti pembelajaran PAUD adalah pemberian stimulasi secara tepat, bukan pelajaran mengenai berbagai teori seperti di SD maupun sejenisnya. Inilah sebabnya, kenapa di TK lebih banyak bermain, bernyanyi dan bercerita daripada menghitung dan menulis. Sebab, bermain, bernyanyi, dan bercerita merupakan stimulasi yang lebih daripada belajar menghitung dan menulis bagi anak usia dini.

Hal ini senada yang dikemukakan oleh Jean Pieget bahwa anak belajar melalui interaksi dengan lingkungannya atau dunianya. Dunia adalah dunia bermain. Dengan demikian anak belajar dengan cara bermain, bukan dengan belajar sebagaimana orang dewasa belajar.

Maria Montessori lebih tegas menyatakan bahwa semua anak belajar dengan bermain. Bermain dikalangan anak-anak sama halnya dengan kerja 
pada orang tua atau belajar pada orang dewasa. Mungkin, orang dewasa memandang bahwa permainan adalah main-main yang tanpa keseriusan, tetapi banyak anak-anak, bermain adalah kerja yang dilakukan dengan penuh kesungguhan. Dengan kata lain, anak-anak sungguh-sungguh bermain. Dengan istilah lain, pekerjaan anak-anak adalah bermain. Maria Montessori menggunakan tiga prinsip utama memberikan permainan pada anak. Pertama, pendidikan usia dini (early childhood). Kedua, lingkungan pembelajaran (the learn environment). Ketiga, peran guru (the role of the teacher). ${ }^{2}$

Sedikit berbeda dengan Motessory, Elizabeth Hurlock mendefinisikan bermain sebagai aktivitas untuk memperoleh kesenangan.Lebih lanjut, Hurlock menegaskann bahwa bermain merupakan lawan dari kerja. ${ }^{3}$ Jika bermain dilakukan dengan penuh kesenangan dan kebahagian, maka belajar belum tentu harus dilakukan dengan kebahagian; jika bermain dilakukan dengan tanpa beban, maka belajar harus dilakukan dengan beban kewajiban tertentu; jika bermain dilakukan dengan tanpa tujuan atau hasil, maka belajar selalu berorientasi pada hasil.

Bermain adalah aktivitas yang sangat menyenangkan dengan ditandai gerak tawa oleh anak yang melakukan. Sebab tawa adalah tanda dari kegiatan bermain da nada di dalam aktivitas sosial. Mayke menyatakan bahwa istilah bermain merupakan konsep yang tidak mudah untuk dijabarkan.Bahkan dalam kamus Oxford English Dictionary, tercantum 116 definisi tentang bermain.Masing-masing devinisi yang dikemukakan sangat berbeda, bahkan seringkali berlawanan. Ada yang berpendapat bahwa bermain adalah kegiatan yang diulang-ulang demi kesenangan, sedangkan pendapat yang lain

\footnotetext{
${ }^{2}$. Lesley Britton, Montessori Play \& Learn; A Parents' Guide Purposeful Play from Two to Six, (New York: Crown Publishers, 1992), hlm. 39

${ }^{3}$. Elizabeth Hurlock, Perkembangan anak, jilid I, alih bahasa dr. Meitasari Tjandrasa \& Dra. Muslichah Zarkasih, (Jakarta: Erlangga, 1978), hlm. 107
} 
mengatakan seringkali bermain tidak semata-mata untuk meraih kesengan tetapi juga prestasi tertentu. Berikut ciri-ciri bermain:

1. Dilakukan atas pilihan sendiri, motivasi pribadi, dan untuk kepentingan sendiri.

2. Anak yang melakukan aktivitas bermain mengalami emosi-emosi positif.

3. Adanya unsur fleksibilitas, yaitu mudah ditinggalkan untuk beralih ke aktivitas yang lain dengan tanpa beban.

4. Tidak ada tekanan tertentu atas permainan tersebut, sehingga tidak ada target yang harus dicapai.

5. Bebas memilih. Ciri ini mutlak bagi anak usia dini.

6. Melalui kualitas pura-pura, seperti anak memegang kertas dilipat purapura menjadi pesawat dan sejenisnya.

Atas dasar ini, sebenarnya anak mampu melakukan percobaan dan penelitian sendiri melalui eksplorasi berbagai permainan yang dilakukannya. Guru hanya bisa menuntun anak-anak dengan menyediakan bahan-bahan permainan yang tepat, tetapi yang terpenting agar anak dapat memahami sesuatu, ia harus membangun penegrtian itu sendiri, dan ia harus menemukannya sendiri.

\section{A. Anak dalam Prespektif Psikologi}

Menurut Damaiyanti (2008), karakteristik anak sesuai tingkat perkembangan:

a. Usia bayi (0-1 tahun)

Pada masa ini bayi belum dapat mengekspresikan perasaan dan pikirannya dengan kata-kata.Oleh karena itu, komunikasi dengan bayi lebih banyak menggunakan jenis komunikasi non verbal. Pada saat lapar, haus, basah dan perasaan tidak nyaman lainnya, bayi hanya bisa mengekspresikan -80 -

Al Marhalah : Jurnal Pendidikan Islam. Volume. 1, No.2 November 2017 
perasaannya dengan menangis. Walaupun demikian, sebenarnya bayi dapat berespon terhadap tingkah laku orang dewasa yang berkomunikasi dengannya secara non verbal, misalnya memberikan sentuhan, dekapan, dan menggendong dan berbicara lemah lembut.Ada beberapa respon non verbal yang biasa ditunjukkan bayi misalnya menggerakkan badan, tangan dan kaki. Hal ini terutama terjadi pada bayi kurang dari enam bulan sebagai cara menarik perhatian orang. Oleh karena itu, perhatian saat berkomunikasi dengannya. Jangan langsung menggendong atau memangkunya karena bayi akan merasa takut. Lakukan komunikasi terlebih dahulu dengan ibunya. Tunjukkan bahwa kita ingin membina hubungan yang baik dengan ibunya.

b. Usia pra sekolah (2-5 tahun)

Karakteristik anak pada masa ini terutama pada anak dibawah 3 tahun adalah sangat egosentris. Selain itu anak juga mempunyai perasaan takut oada ketidaktahuan sehingga anak perlu diberi tahu tentang apa yang akan akan terjadi padanya. Misalnya, pada saat akan diukur suhu, anak akan merasa melihat alat yang akan ditempelkan ke tubuhnya. Oleh karena itu jelaskan bagaimana akan merasakannya. Beri kesempatan padanya untuk memegang thermometer sampai ia yakin bahwa alat tersebut tidak berbahaya.

untuknya. Dari hal bahasa, anak belum mampu berbicara fasih. Hal ini disebabkan karena anak belum mampu berkata-kata 900-1200 kata. Oleh karena itu saat menjelaskan, gunakan kata-kata yang sederhana, singkat dan gunakan istilah yang dikenalnya.Berkomunikasi dengan anak melalui objek transisional seperti boneka. Berbicara dengan orangtua bila anak malu-malu. Beri kesempatan pada yang lebih besar untuk berbicara tanpa keberadaan orangtua. Satu hal yang akan mendorong anak untuk meningkatkan 
kemampuan dalam berkomunikasi adalah dengan memberikan pujian atas apa yang telah dicapainya.

c. Usia sekolah (6-12 tahun)

Anak pada usia ini sudah sangat peka terhadap stimulus yang dirasakan yang mengancam keutuhan tubuhnya. Oleh karena itu, apabila berkomunikasi dan berinteraksi sosial dengan anak diusia ini harus menggunakan bahasa yang mudah dimengerti anak dan berikan contoh yang jelas sesuai dengan kemampuan kognitifnya. Anak usia sekolah sudah lebih mampu berkomunikasi dengan orang dewasa. Perbendaharaan katanya sudah banyak, sekitar 3000 kata dikuasi dan anak sudah mampu berpikir secara konkret. Perkembangan anak didasari faktor internal dan faktor ekstrernal (lingkungan).

d. Usia remaja (13-18)

Fase remaja merupakan masa transisi atau peralihan dari akhir masa anak-anak menuju masa dewasa.Dengan demikian, pola pikir dan tingkah laku anak merupakan peralihan dari anak-anak menuju orang dewasa.Anak harus diberi kesempatan untuk belajar memecahkan masalah secara positif. Apabila anak merasa cemas atau stress, jelaskan bahwa ia dapat mengajak bicara teman sebaya atau orang dewasa yang ia percaya. Menghargai keberadaan identitas diri dan harga diri merupakan hal yang prinsip dalam berkomunikasi. Luangkan waktu bersama dan tunjukkan ekspresi wajah bahagia

secara umum psikolog anak sendiri terbagi menjadi psikolog pendidikan yang berfokus dalam hal memberikan dukungan kepada anak dalam dunia pendidikan, dan psikolog klinis yang berfokus dalam memberikan dukungan kepada anak-anak yang memiliki hambatan atau gangguan dalam proses perkembangan mereka. 
Psikologi anak sendiri merupakan bagian dari cabang ilmu psikologi lainnya, yaitu psikologi perkembangan yang mempelajari pertumbuhan manusia semenjak lahir sampai menjadi dewasa. Psikologi perkembangan sendiri mempelajari bagaimana dan mengapa manusia berubah dalam setiap tahapan hidupnya.

Pada awalnya psikologi perkembangan lebih berfokus kepada bayi dan anak-anak, namun sekarang psikologi perkembangan juga mencakup semua tahapan usia lainnya lainnya, seperti masa pra-remaja, remaja, dewasa dan masa tua. Bidang psikologi ini menyelidiki perubahan yang terjadi dan meliputi berbagai macam topic seperti kemampuan motorik, perkembangan kognitif, kemampuan mengalami keputusan, pemahaman moral, pemahaman bahasa, perubahan sosial, kepribadian, perkembangan emosional, konsep tentang diri sendiri dan pembentukan identitas.

Psikologi perkembangan menyelidiki pengaruh dari natur dan nurture pada proses tumbuh kembang manusia dan juga berbagai proses perubahan di berbagai waktu. Banyak para periset yang tertarik pada interkasi antara karakter personal, perilaku individu dan faktor lingkungan sekitar termasuk di dalamnya konteks sosial dan pembentukan lingkungan.

Faktor internal ini bisa dinilai dari metode tes IQ untuk menguji kepandaian anak.Tes IQ menghadapkan anak dengan sejumlah pertanyaan dan membandingkan jawaban dari masing-masing anak dengan hasil yang dicapai oleh rata-rata anak di dalam usia yang sama, dari sini anak-anak mungkin berpikir dengan cara yang sama sekali berbeda dibandingkan 
dengan orang dewasa, yang mana hal tersebut tidak mungkin hanya karena kurangnya pengalaman semata. ${ }^{4}$

Faktor eksternal ini dilihat dari anak mempelajari dunia melalui interaksi yang dilakukannya dan ia bergerak secara alamiah. ${ }^{5}$ Tumbuh kembang terjadi pertama kali melalui interaksi sosial yang dilakukan oleh anak-anak lalu baru bergerak pada level individu di mana mereka mengambil makna dari apa yang mereka pelajari.

\section{a. Karakteristik Anak Usia dini}

Masa awal kanak-kanak merupakan usia yang sulit. Usia itu sebagai usia penting bagi pengembangan potensi yang dimiliki anak, mereka juga menyerap informasi yang sangat tinggi. Proses ini berlangsung dengan disertai dengan prilaku-prilaku yang kurang menarik, misalnya melawan orang tua, marah tanpa alasan, takut yang tidak rasional, dan diseringi juga rasa cemburu. Ada 3 kriteria praktis dan mudah di terapkan untuk mengetahui keadaan anak yang telah encapai masa peka (siap ajar), yaitu:

1. Minat belajar. Anak dikatakan siap belajar ketika ia mulai menunjukkan minat belajar dengan keinginan untuk diajar atau belajar sendiri. Minat mulai timbul dari keinginan anak untuk meniru saudara kandung atau temannya yang lebih besar.

\footnotetext{
${ }^{4}$. Pendapat ini dikenal dengan Teori Jean Piaget, seorang Psikologi Klinis dari Swiss.Ia dikenal luas karyanya yang mempelopori pemahaman mengenai tumbuh kembang anak. Piaget yang pada awalnya adalah seorang guru dan ahli biologi menjadi tertarik untuk mengembangkan metode baru untuk menguji kepandaian anak tidak lama sesudah Perang Dunia I. Tes IQ (Intelligence Quotient) merupakan tes yang awalnya dikembangkan oleh para psikolog untuk anak-anak di Prancis yang dianggap memiliki resiko hambatan dalam perkembangan mereka.

5. Pendapat ini dikenal dengan Teori Lev Semyonovich Vygotsky, iaseorang psikolog asal Uni Soviet yang pada saat hampir bersamaan telah mencapai kesimpulan yang mirip dengan kesimpulan Piaget mengenai tumbuh kembang anak.
}

- 84 -

Al Marhalah : Jurnal Pendidikan Islam. Volume. 1, No.2 November 2017 
2. Minat yang bertahan. Ketika anak telah siap belajar, minat mereka tetap walaupun mereka menghadapi hambatan dan kesulitan.

3. Kemajuan. Dengan berlatih anak yang telah siap belajar akan menunjukkan kemajuan walaupun sedikit dan berangsurangsur. $^{6}$

Masa peka merupakan periode dimana anak telah mencapai kesiapan untuk belajar. Betapapun banyaknya rangsangan yang diterima anak,mereka tidak dapat belajar sampai perkembangan mereka siap untuk melakukannya.

Perkembangan masing-masinga anak berbeda ada yang cepat ada yang lambat, tergantung faktor bakat dan lingkungan, oleh sebab itu perlakuan terhadap anak tidak dapat disamaratakan, sebaiknya dengan mempertimbangkan tingkat pertumbuhan dan perkembangana anak. Setiap anak itu unik, tidak dapat membanding-bandingkannya dengan anak yang lain, yang perlu kita lakukan adalah membantu mengenali potensi dan mengarahkannya. Munculnya potensi anak memang tergantung pada rangsangan yang diberikan, karena itu kita wajib untuk menggali sekaligus mengembangkan potensi anak sejak dini, makin dini anak menerima stimulus maka makin baik. Untuk mengembangkan potensi tersebut makan kita harus memahami ciriciri berfikir anak.

Menguraikan ciri-ciri berfikir anak usia dini sesuai dengan teori piaget, terdiri dari :

1. Berfikir secara konkret

\footnotetext{
${ }^{6}$. Elizabeth Hurlock, Perkembangan anak, jilid I, alih bahasa dr. Meitasari Tjandrasa \& Dra. Muslichah Zarkasih, (Jakarta: Erlangga, 1978), hlm. 10-11
} 
2. Realisme

3. Egosentris

4. Kecenderungan untuk berfikir

5. Animisme

6. Sentrasi

7. Memiliki imajinasi yang sangat kaya, ${ }^{7}$

Pada kenyataannya, masih terdapat sebagian besar orang tua dan guru yang belum memahami akan potensi luar biasa yang dimiliki anak usiadini. Keterbatasan pengetahuan dan informasi yang dimiliki orang tuadan guru menyebabkan potensi yang dimiliki anak tidak berkembang optimal.

\section{b. Sosial Anak Usia Dini}

Perilaku sosial pada anak usia dini ditunjukan melalui aktivitas dalam berhubungan dengan orang lain, orang tua maupun saudara- saudara nya. Sejak kecil anak telah belajar cara berperilaku sosial sesuai dengan harapan orang-orang didekatnya, yaitu dengan ibu, ayah, saudara dan anggota keluarga lainnya. Dalam kajian sosiologis, definisi sosial yang disebut dengan proses sosial yaitu cara-cara berhubungan yang dilihat apabila perorangan dan kelompok-kelompok sosial saling bertemu dan menentukan sistem serta bentuk-bentuk hubungan ini,atau apayang akan terjadi apabila ada perubahan-perubahan yang menyebabkan goyahnya pola-pola kehidupan yang telah ada. ${ }^{8}$

Hal ini sejalan dengan perkembangan sosial emosional anak yang menyangkut perkembangan bersosialisasi dan bagaimana pengendalian perasaan anak.

\footnotetext{
7. Conny R. Semiawan, Penerapan Pembelajaran Anak, (Jakarta: Indeks, 2009), hlm. 43

8. Ahmad Susanto, Teori Belajar \& Pembelajaran di Sekolah Dasar, (Jakarta: Prenada Media, 2014), hlm. 135

- 86 -
}

Al Marhalah : Jurnal Pendidikan Islam. Volume. 1, No.2 November 2017 


\section{c. Emosional Anak Usia Dini}

Jika kita bicara tentang emosi maka setiap orang akan mengatakan bahwa ia pernah merasakannya. Hidup manusia sangat kaya akan pengalaman emosional, hanya saja ada yang sangat kuat dorongannya dan ada yang sangat samar sehingga ekspresinya tidak sama. Ekspresi emosi pada jenjang usia mulai dari bayi dan orang dewasa berbeda. Sebagai contoh, seorang anak menangis saat mainan yang dimiliki di rebut oleh kakaknya, perilaku tersebut menunjukan gambaran emosi seseorang.

Jadi definisi dari emosi yaitu suatu keadaan yang kompleks pada diri organisme, yang meliputiperubahan secara badaniah dalam bernapas, yang meliputi perubahan secara badaniah dalam bernapas, detak jantung, perubahan kelenjar dan kondisi mental seperti keadaan menggembirakan yang ditandai dengan perasaan yang kuat dan biasanya disertai dengan dorongan yang mengacu pada suatu bentuk prilaku. ${ }^{9}$

Jadi dapat disimpulkan bahwa emosional adalah perpaduan daripengalaman afektif berupa pergolakan fikiran, napsu, keadaan mental dan fisik yang dapat muncul dalam bentuk atau gejala-gejala seperti takut, cemas, marah, murung, iri, cemburu, kasih sayang dan ingin tahu sebagai respon dari penyesuaian dalam diri individu.

\section{d. Karakteristik Sosial dan Emosional Anak Usia Dini}

Perkembangan sosial anak usia dini diperoleh melalui pengalaman belajar atau situasi lingkungan dimana anak berinteraksi dengan lingkungannya. Umumnya anak usia dini memiliki beberapa sahabat, tetapi mudah berganti. Sahabat yang dipilih biasanya memiliki jenis kelamin yang sama, dan akhirnya berkembang kepada jenis kelamin yang

\footnotetext{
9 . Riana Mashar, Emosi Anak Usia Dini dan Strategi Pengembangannya, (Jakarta: Prenada Media, 2011), hlm. 16
} 
berbeda.Mengamati tingkah laku sosial anak usia dini ketika mereka sedang bermain bebas sebagai berikut:

1. Tingkah Laku Unoccupied

Anak tidak bermain dengan sesungghunya. Ia mungkin berdiri disekitar anak lain dan memandang temannya tanpa melakukan kegiatan apapun.

2. Bermain Soliter

Anak bermain sendiri dengan menggunakan alat permainan berbeda dengan apa yang dimainkan dengan teman yang ada didekatnya mereka tidak berusaha untuk saling bicara.

3. Tingkah Laku Onlooker

Anak menghabiskan waktu dengan mengamati. Kadang memberi komentar tentang apa yang dimainkan anaklain, tetapi tidak berusaha untuk bermain bersama.

4. Bermain Parallel

Anak bermain dengan saling berdekatan tetapi tidak sepenuhnya bermain bersama dengan anak lain.

5. Bermain Asosiatif

Anak bermain dengan anak lain tetapi tanpa organisasi.

6. Bermain Kooperatif

Anak bermain dalam kelompok dimana ada organisasi, ada pimpinannya. $^{10}$

Anak usia dini memiliki beragam kelompok bermain cenderung kecil tidak terorganisasi secara baik, oleh karena itu kelompok- kelompok tersebut selalu cepat berganti. Anak usia dini cenderung mengekspresikan emosinya secara bebas,sikap marah, menangis, mencari perhatian sering terjadi. Anak

10. Ahmad Susanto, Teori Belajar \& Pembelajaran di Sekolah Dasar, (Jakarta: Prenada Media, 2014), hlm. 148-149

- 88 -

Al Marhalah : Jurnal Pendidikan Islam. Volume. 1, No.2 November 2017 
juga mudah marah jika tidak dapat melakukan sesuatu yang dianggap dapat dilakukannya dengan mudah. Pola-pola emosi umum pada awal masa kanakkanak meliputi aspek yaitu rasa takut, rasa malu, rasa khawatir, rasa cemas, rasa marah, rasa cemburu, rasa duka cita, rasa ingin tahu dan rasakegembiraan. ${ }^{11}$ Bila pola emosional tersebut dipetakan dalam sebuah tabel maka akan tampak sebagai berikut:

\begin{tabular}{|c|l|l|l|}
\hline No & \multicolumn{1}{|c|}{ Pola Emosi } & \multicolumn{1}{|c|}{ Rangsangan } & \multicolumn{1}{c|}{ Reaksi } \\
\hline 1 & Takut & $\begin{array}{l}\text { Suara keras, gelap, } \\
\text { binatang, dan rasa } \\
\text { sakit }\end{array}$ & $\begin{array}{l}\text { Lemas tak berdaya, dan } \\
\text { teriak minta tolong }\end{array}$ \\
\hline 2 & Malu & $\begin{array}{l}\text { Orang yang baru } \\
\text { dikenal }\end{array}$ & $\begin{array}{l}\text { Menangis dan } \\
\text { memalingkan muka }\end{array}$ \\
\hline 3 & Khawatir & $\begin{array}{l}\text { Melebih-lebihkan, } \\
\text { kekurangan, dan } \\
\text { mengkhayalkannya }\end{array}$ & Wajah terperangai khawatir \\
\hline 4 & Cemas & $\begin{array}{l}\text { Pesimis dan } \\
\text { Terpojok }\end{array}$ & $\begin{array}{l}\text { Murung, gugup dan mudah } \\
\text { tersinggung }\end{array}$ \\
\hline 5 & Marah & $\begin{array}{l}\text { Rintangan dan } \\
\text { Pembatasan }\end{array}$ & $\begin{array}{l}\text { Diam, berkata kasar, dan } \\
\text { tidak anarkis }\end{array}$ \\
\hline 6 & Cemburu & Kurang perhatian & Tidak aman dan raguragu \\
\hline 7 & Duka Cita & $\begin{array}{l}\text { Hilanganya } \\
\text { sesuatu yang } \\
\text { dicintai }\end{array}$ & $\begin{array}{l}\text { Menangis dan sukar } \\
\text { tidur }\end{array}$ \\
\hline 8 & Rasa Ingin Tahu & $\begin{array}{l}\text { Segala hal yang } \\
\text { baru }\end{array}$ & $\begin{array}{l}\text { Mengerutkan dahi dan } \\
\text { membuka mulut }\end{array}$ \\
\hline 9 & Kegembiraan & $\begin{array}{l}\text { Fisik yang sehat, } \\
\text { permainan, dan } \\
\text { sesuatu yang ganji }\end{array}$ & $\begin{array}{l}\text { Tertawa, merangkak, } \\
\text { berjalan dan lari }\end{array}$ \\
\hline
\end{tabular}

Berdasarkan tabel di atas Emosi dapat dicerdaskan sedemikian rupa, sehingga kecerdasan emosional menunjang pembentukan pribadi yang baik.

\footnotetext{
${ }^{11}$. Elizabeth Hurlock, Perkembangan anak, jilid I, alih bahasa dr. Meitasari Tjandrasa \& Dra. Muslichah Zarkasih, (Jakarta: Erlangga, 1978), hlm. 110
}

Al Marhalah : Jurnal Pendidikan Islam. Volume. 1, No. 2 November 2017 
Rentang usia 5-6 tahun merupakan masa terbentuknya pola dalam bertingkah laku sosial anak usia dini. Perkembangan sosial pada anak usia dini memiliki beberapa faktor yang dapat mempengaruhi perkembangan itu sendiri sebagai pendidik seorang guru harus mengetahui faktor apa yang mempengaruhi karena dengan pemahaman tersebut guru dapat mengetahui cara menstimulus perkembangan sosial anak secara tepat.

Faktor-faktor yang dapat mempengaruhi perkembangan sosial anakusia dini yaitu:

1. Adanya kesempatan untuk bergaul dengan orang- orang yang ada disekitarnya dengan berbagai usia dan latar belakang.

2. Adanya minat dan motivasi untuk bergaul.

3. Adanya bimbingan dan pengajaran dari orang lainyang biasanya menjadi model untuk anak.

4. Adanya kemampuan berkomunikasi yang baik yang dimiliki anak.

Pada periode pra-sekolah anak dituntut untuk mampu menyesuaikan diri dengan berbagai orang. Misalnya keluarga,teman sekolah dan teman sebaya.

Faktor faktor yang menyebabkan perkembangan emosi anak adalahsebagai berikut:

1. Kesadaran koognitifnya yang telah meningkat memungkinkan pemahaman terhadap lingkungan berbeda dari tahap semula.

2. Imajinasi atau daya hayalnya lebih berkembang.

3. Berkembang wawasan sosial anak. ${ }^{12}$

Berdasarkan teori di atas dapat disimpulkan bahwa faktor yangmempengaruhi sosial emosional anak usia dini harus diperhatikankarena mampu menimbulkan gangguan yang mencemaskan parapendidik dan orang tua.

${ }^{12}$. Elizabeth Hurlock, Perkembangan anak, jilid I, alih bahasa dr. Meitasari Tjandrasa \& Dra. Muslichah Zarkasih, (Jakarta: Erlangga, 1978), hlm. 30

- 90 -

Al Marhalah : Jurnal Pendidikan Islam. Volume. 1, No.2 November 2017 


\section{B. Pendidikan dalam Anak Usia Dini}

Berdasarkan psikologi Anak usia dini yang di atas, jelas bahwa pendidikan bisa masuk ke ranah anak usia dini, yang dikenal dengan PAUD atau PIAUD (Pendidikan Islam Anak Usia Dini). Secara Filosofis, pendidikan adalah suatu upaya untuk membantu memanusiakan manusia, artinya melalui proses pendidikan diharapkan terlahir manusia-manusia yang lebih baik. Dalam pengertian yang lebih kongkret, anak harus lebih baik daripada orang tuanya.

Standar manusia "baik" ternyata berbeda-beda antara masyarakat, bangsa atau Negara yang satu dengan yang lain. Perbedaan ini disebabkan adanya perbedaan pandangan filsafat yang menjadi keyakinan masingmasing orang, masyarakat, bangsa dan Negara.Perbedaan falsafah ini membawa perbedaan dalam orientasi atau tujuan pendidikan.

Anak sebagai makhluk individual dan sosial yang sangat berhak untuk mendapatkan pendidikan yang sesuai dengan kebutuhan dan kemampuannya. Dengan pendidikan yang diberikan diharapkan anak tumbuh-kembang secara cerdas sesuai dengan potensi yang dimilikinya, sehingga kelak dapat menjadi anak bangsa yang berkualitas.

Atas dasar ini PAUD hendak mecetak generasi-generasi yang cerdas sejak usia dini. Sebab, usia dini merupakan masa yang paling tepat untuk memberikan karakter seseorang. Jika pada masa ini karakter setiiap anak berhasil dibentuk, maka kelak di masa dewasa akan menjadi generasi yang berkarakter kuat. Sebab, $80 \%$ karakternya telah tertanam menjadi baik.Inilah sebabnya, keberadaan Paud menjadi keniscayaan.

\section{a. Metode Collaborative Learning}

Metode colaborative learning merupakan salah satu model pembelajaran yang digunakan di PAUD, metode ini mengajarkan kepada 
siswa untuk memiliki kepedulian terhadap satu sama lain. Definisi collaborative learning dirujuk menggunakan frase pembelajaran kolaboratif yang sengaja dirancang dan dilaksanakan secara berpasangan atau dalam kelompok kecil, walau sebenarnya definisi collaborative learning yang fleksibel adalah yang tebaik, namun ada beberapa fleksibel yang dianggap penting:

1. Pembelajaran kolaboratif adalah disain yang di sengaja

2. Kerjasama

3. Pembelajaran kolaboratif adalah terjadinya proses pembelajaran yang penuh makna. ${ }^{13}$

Definisi lain yang menjelaskan pengertian collaborative learning adalah metode pembelajaran yang menerapkan paradigma baru dalam teoriteoribelajar khususnya pembelajaran konstruktivisme. ${ }^{14}$

Berdasarkan penjabaran di atas maka dapat disimpulkan bahwa collaborative learning adalah pembelajaran yang didesain secara sengaja oleh pengajar, dalam bentuk desain kegiatan kerja kelompok agar siswa dapat bekerja sama sehingga terjadi proses pembelajaran yang bermakna.

\section{b. Karakteristik Collaborative Learning}

Collaborative Learning adalah proses belajar mengajar yang menggunakan kelompok-kelompok kecil yang memungkinkan siswa untuk bekerja bersama-sama dan memberikan manfaat satu sama lain. Collaborative learning dapat digunakan dalam berbagai macam cara yang meliputi :

${ }^{13}$. Elizabert E. Barkley, Collaborative Learning Techniques - Teknik-Teknik Pembelajaran Kolaboratif, (Jakarta: Nusa Media, 2012), hlm. 5

14. Vygotsky, L. S. Development of Children and the process of learning, (M. Lopes Murillas.Terj.), (Cambridge. MA: Harfard University press, 1934), hal.185. Dalam bukunya William Crain, Teori perkembangan/konsep dan aplikasi, (Yogyakarata: Pustaka Pelajar:2007), hlm.369

- 92 -

Al Marhalah : Jurnal Pendidikan Islam. Volume. 1, No.2 November 2017 
1. Pembelajaran kolaboratif formal adalah suatu bentuk pembelajaran kelompok dimana siswa bekerja secara bersama-sama, pada jam pelajaran tertentu untuk menyelesaikan tugas belajar yang di berikan.

2. Pembelajaran kolaboratif Informal adalah pembelajaran kelompokkelompok yang bersifat sementara dan khusus yang bertahan sekitar beberapa menit saja dalam satu periode kelas.

3. Kelompok-kelompok kolaboratif inti adalah kelompok pembelajaran jangka panjang.

4. Struktur kolaboratif adalah naskah pembelajaran kelompok berupa prosedur standar dan bebas konten, yang menuntut siswa untuk bertindak langkah demi langkah. ${ }^{15}$

Berdasarkan penjabaran beberapa cara metode collaborative learning di atas maka dapat disimpulkan cara yang dapat digunakan dalam pembelajaran kolaboratif adalah pembelajaran kooperatif formal.

Ada banyak skil interpersonal yang mempengaruhi keberhasilan usaha-usaha kolaboratif yaitu :

1. Forming (membentuk) - kemampuan paling dasar yangdibutuhkan untuk menciptakan kelompok pembelajaran kelompok yang berfungsi.

2. Functionong (memungsikan) - kemampuan yang dibutuhkan untuk mengelola kegiatan kelompok dalam menyelesaikan tugas dan menjaga hubungan kerja yang efektif diantara para anggota.

3. Formulating (merumuskan) - kemampuan yang dibutuhkan untuk membangun pemahaman yang lebih dalam terhadap materi yang sedang di pelajarai.

${ }^{15}$. Elaine B. Johnson, Contextual Teaching and Learning, (Jakarta: Kaifa, 2012), hlm. 11

Al Marhalah : Jurnal Pendidikan Islam. Volume. 1, No. 2 November 2017 
4. Fermenting (mengembangkan) - kemampuan yang dibutuhkan untuk menstimulus rekonseptualisasi materi yang sedang dipelajari, konflik, dan pencarian lebih banyak informasi. ${ }^{16}$

Berdasarkan pernyataan bahwa skil-skil dalam metode collaborative learning perlu diterapkan guru karena anak tidak dilahirkan dengan kemampuan mengetahui tentang bagaimana berinteraksi dengan orang lain dan skil kelompok sertain terpersonal tidak muncul begitu saja secara ajaib ketika dibutuhkan. Sehingga guru harus mengajarkan skil-skil kolaboratif pada anak, untuk meningkatkan kemampuan sosial anak.

\section{Penutup}

Anak usia dini berhak mendapatkan pendidikan, sebagaimana undang-undang no. 20 Tahun 2003 tentang Pendidikan Nasional bab 1, pasal 1, butir 14 yang menyatakan Pendidikan Anak Usia dini adalah upaya pembinaan yang ditujukan kepada anak sejak lahir sampai usia 6 tahun yang dilakukan melalui pemberian rangsangan pendidikan untuk membantu pertumbuhan dan perkembangan jasmani dan rohani agar anak memiliki kesiapan dalam memasuki pendidikan lebih lanjut.

\section{Daftar Pustaka}

Montessori, Maria, 2000, Metode Montessori (Panduan Guru Dan Orang Tua Didik Paud), Yogyakarta: Pustaka Pelajar

Britton, Lesley, 1992, Montessori Play \& Learn; A Parents' Guide Purposeful Play from Two to Six, New York: Crown Publishers

Hurlock, Elizabeth, 1978, Perkembangan anak, jilid I, alih bahasa dr. Meitasari Tjandrasa \& Dra. Muslichah Zarkasih, Jakarta: Erlangga

\footnotetext{
${ }^{16}$. Elaine B. Johnson, Contextual Teaching and Learning, (Jakarta: Kaifa, 2012), hlm. 113 - 94 -
}

Al Marhalah : Jurnal Pendidikan Islam. Volume. 1, No.2 November 2017 
Semiawan, Conny R., 2009, Penerapan Pembelajaran Anak, Jakarta: Indeks

Susanto, Ahmad, 2014, Teori Belajar \& Pembelajaran di Sekolah Dasar, Jakarta: Prenada Media

Mashar, Riana, 2011, Emosi Anak Usia Dini dan Strategi Pengembangannya, Jakarta: Prenada Media

S., Vygotsky, L., 1934, Development of Children and the process of learning, (M. Lopes Murillas. Terj.), Cambridge. MA: Harfard University press

Crain, William, 2007, Teori Perkembangan/Konsep dan Aplikasi, Yogyakarata: Pustaka Pelajar

Johnson, Elaine B., 2012, Contextual Teaching and Learning, Jakarta: Kaifa 